\title{
An Investigation into the Disciplinary Measures used in South African Schools: How Effective are they to the Learners?
}

John Wankah Foncha

Mzukisi Howard Kepe

Jane-Francis Afungmeyu Abongdia

Faculty of Education, University of Fort Hare

jabongdia@ufh.ac.za/jfoncha@ufh.ac.za

Doi:10.5901/mjss.2014.v5n23p1160

\section{Introduction and Background}

The gaining ground concern on the increasing cases of learner's indiscipline in schools currently and during the past number of years has become a bone of contention in schools. This has also been observed by other researchers in this discipline who perceive that indiscipline has led to concerns about academic performance, safety and security apprehensions in schools. In addition, there have been cases of serious injuries and fatalities within school premises in some schools in South Africa (Ngcukana, 2009). The problem of learner's indiscipline has been characterized as grave and pervasive, unconstructively affecting student's learning (Holden, 2002). The aforesaid problem manifests itself in a variety of ways which include disruptive learners, vandalism, truancy, smoking, disobedience, intimidation, delinquency, murder, assault, rape, theft and general violence (De Wet, 2003: 168). Wilde (1995) is also disturbed by such happenings and argues that with rampant indiscipline as displayed in the various forms mentioned above, teaching and learning have become difficult. Wilde (1995) further points out inter alia that answering back, talking 'out of turn', getting out of seats 'without permission' and general rowdiness are habitual in schools. In view of this, De Wet (2003) notes that without doubt if schools encounter proliferating ill-discipline as exhibited above, the core business of teaching and learning has turned out to be difficult if not impossible. It is on these grounds that this study is eager to find ways of bringing back discipline as it is apparent that the alternatives for corporal punishment are not working. In other words, the study strives to look for alternatives to ATCP.

The above doubt is based on the fact that for the better part of the twentieth century, corporal punishment was central for most teachers and learners in South African Schools (Wolfgang, 2001). But with the advent of democracy in 1994 amidst transformation, one change in the educational arena was the outlawing of Corporal punishment in all schools in terms of the South African Schools Act (Republic of South Africa 1996b). The new constitutional and legislative framework and policies had implications on how schools should maintain learner's discipline (Ramadiro and Vally, 2005). The provisions were delineated in the constitution and other statutes amid them SASA (Zaibert, 2006). SASA provided the establishment of the code of conduct in all schools. It prohibited corporal punishment and proposed its alternatives (RSA, 1996). Hence, the Department of Education (2000) endorsed the Alternatives (ATCP) which is in place at the moment. Nevertheless, research is ambivalent concerning the usefulness of ATCP which leads this researcher to the impression that by its standard it seems not to be operative in the manner it is hailed by the DoE. This is meant to say that ATCP is not at all playing the role that corporal punishment used to play and there is need to seek other means and majors to instil discipline in our schools so that learners can become disciplined and more responsible.

The main objective of this study is to capture both learners and educators' views on the effectiveness of disciplinary measures used in schools and classrooms. The intention is to find out how the disciplinary measures used can achieve the desired goals with the view to suggest disciplinary approaches that can lead to the development of selfdiscipline and responsible behaviour in learners as compared to ATCP which is punitive in nature.

\section{Review of Literature}

There is growing concern on the ever increasing cases of indiscipline in South African schools (Cheunyane 2008). As 
noted earlier in the introduction, indiscipline has led to safety and security concerns in schools (Mnyaka 2006). There have been reported cases of serious injuries and fatalities in some schools in South Africa (Ngcukana 2009). School authorities and educators are known to be in a dilemma as they seek to find effective ways of dealing with issues of indiscipline while at the same time protecting the rights of children as demanded by the country's Constitution. The issue of coming up with effective ways of dealing with indiscipline by this study may assist in curbing indiscipline in schools. This could help to ensure safe and secure schools as conducive environments for meaningful teaching and learning (Maphosa and Mammen 2011). Punishment-based disciplinary measures may only help to deter inappropriate behaviours in so far as they provoke fear in learners (Holden 2002). Children come to fear for their possessions (that they may be taken away), privileges (that they may be revoked), preferences (that they may be used against them) and even safety and well being (Zaibert 2006).

In this view, a learner does not necessarily come to understand why behaviour is wrong, or how behaviour negatively impacts on others (McConville 2003). In contrast, the effects of discipline on learners ought to instil an increased sense of responsibility, self-confidence and the ability to distinguish appropriate from inappropriate behaviour (Wolfgang 2001). Punishment, like suspension, detention or expulsion, or the deliberate infliction of unpleasantness on someone judged to have done wrong (ATCP), may be very tempting to educators (Mcconville 2003). It is very important for educators to avoid making learners feel bad in response to their own bad behaviour. Based on the above, punishment cannot teach a learner anything other than that it is alright to hurt others (Zaibert 2006). Instead, educators should strive to discipline their learners in order to help them better themselves and their situations. Properly disciplined children can grow to be happy, healthy and productive members of not just their family, but also good members of their society as well (Sprague and Walker 2004). While it is a traditional school practice to punish learners, tradition does not justify some ways that could be inappropriate (Maphosa and Mammen 2011). Punishment based disciplinary measures may become excessive, inappropriate, counter-productive and wrong (Zaibert 2006). In clarifying the motives behind discipline and punishment, Ramadiro and Vally (2005: 4) make a comparison which shows that the usefulness of any disciplinary measure is dependent on the motive behind it and the manner in which it is administered. Although it may be a violation of human rights, some authorities seem to argue that when well implemented, a hugely considered harsh form of punishment could be useful (Gershoff 2002). As such, useful disciplinary measures, need to consider the feelings of the learners, by not being harsh, but should rather try to make a learner to learn and ultimately develop habits of selfdiscipline and responsibility.

In addition, the effectiveness of punishment might rest on the extent to which learners are involved in both the formulation and implementation of disciplinary measures in schools. Parkey and Strahan (2002) observe that traditionally, maintenance of good learner discipline has relied on the establishment of rules, targeting misbehaviour and exacting penalties. These are authoritarian approaches that seem to sideline learners' views and feelings by simply expecting these learners to conform to preset adult disciplinary standards. Involvement of learners at school and classroom level in the formulation and implementation of disciplinary measures may help to create a positive school and classroom environment (Noguera 2002).

In line with the above, Noguera (2002) further suggests that effective disciplinary methods should be participatory in nature, where the educators, the school governing body and the learners should partner. This may assists in teaching learners self-discipline contrary to the externally driven disciplinary requirements whose results could be ephemeral or counter-productive.

In view of the above, Moles (1989) observes that learner's involvement in disciplinary issues that affect them may have far reaching and long lasting effects as the learners develop a culture of being part of decision making. Learners learn to accept and comply with school rules as 'theirs'. Moles (1989) notes further that involving learners in all the facets of the educational process could increase social bonding and cooperation between educators and learners. The above view is significant in scenarios where indiscipline in schools is exacerbated by the feeling of antagonism that exists between educators and learners. This is usually a negative effect of 'top-down' management styles. Learners may feel issues are imposed on them and would want to resist them which could let matters to get out of hands.

Based on Moles' observation, the effectiveness of a given disciplinary measure can be assessed by the extent to which it enables the fulfilment of:

- The ability to deter offenders, ability to deter others, teaching self-discipline and teaching behaviour accountability (Gershoff 2002).

- The ability to teach conflict handling strategies, ability to help the offender understand the offence committed, teaching responsible behaviour, helping to teach the offender to consider rights and feeling of others (Wolfgang 2001).

- An effective disciplinary measure should also have the ability to involve learners in its formulation and 
implementation, should be commensurate with the offence committed and should be implemented soon after offence is committed (Ramadiro and Vally 2005).

With the above summarized points against which the effectiveness of any given disciplinary measure could be gauged, it becomes necessary to find common grounds to ascertain the effectiveness of disciplinary measures used in schools.

\section{Research Question}

1. What are learners/educator's views on the effectiveness of disciplinary approaches used in the two schools?

2. What are the views of the learners on effective approaches to discipline in schools?

\section{Methodology}

This paper forms part of Kepe's M Ed on-going thesis in the Faculty of Education, University of Fort Hare, with the coauthor playing the role of his supervisor. The study is premised within the interpretivist paradigm. Interpretivism puts emphasis on the fact that the aim of social sciences is to understand people and not to explain them as assumed by positivism. Thus, it is a narrative of the perspectives of the researched. The qualitative approach was used to interrogate the scope of the research problem. The targeted population of the research comprised two focus groups from each of the two schools, where each group composed of five learners ranging between the ages of thirteen and nineteen. Four teachers and two administrators were interviewed from each school to get their subjective views. In any qualitative research reflexivity is of paramount importance. This is because it will help the researcher to be objective during data collection, data analysis and discussion of the findings. Reflexivity should be accountable for the usage of diverse designs for data collection (triangulation) during knowledge generation.

The data was analysed by arranging it in a logical and chronological order using themes. Categories were identified that helped to cluster the data into meaningful groups. And all ethical protocol was observed as we applied for ethical clearance to the University of Fort Hare, the District office of DoE and the Principals of the two schools.

\section{Analysis and Discussion}

Data on the effectiveness of disciplinary measures used were solicited from two perspectives. The first one was how the teachers conceived individual disciplinary measures for both minor and major forms of indiscipline as they were used in their schools. The following excerpts are from the interviews with the teachers:

Teacher 1: Whenever you follow the alternatives to corporal punishment advises you to do in class, learners instead turn to enjoy it a lot. For instance, when you chose a learner from your class as a form of punishment because that learner was disturbing, that learner would enjoy it and would always want to disturb.

Teacher 4: Some learners like suspension from class or school because it gives them chance to stay away from class or from their homes.

The second was the effectiveness of disciplinary measures for minor and major forms of indiscipline against the parameters of judging the effectiveness of disciplinary measures as revealed in the literature. Most of the disciplinary measures applied for minor forms of indiscipline suggested that they were not very effective when they were used. Sending learners out of class and denying them privileges, should therefore be seen as very ineffective. In view of this, focus group interviews from the learners revealed that;

Learner 1: When classes are very boring sometimes, I have to make a plan so that the teacher will ask me to go out of his class.

Learner 7: My parents are too strict at home and the teachers are strict at school which make school and house boring so I will always commit mischief so that I am left alone.

Learner 8: If I want to go out of the class any time, I will provoke the teacher and she will send me out.

Interviewed educators revealed that some learners actually enjoyed being sent out of class and would commit further acts of indiscipline while on punishment. This affirms Strauss (1996) assertion that punitive disciplinary measures may not really achieve the desired purpose of deterring learners. These writers found an interesting contrast between educators and learners response on the effectiveness of corporal punishment and findings in the literature. 
One very interesting area is that of corporal punishment as some teachers in one of the two schools still use it as a punitive measure. Learners appear to see corporal punishment as a highly effective disciplinary measure yet this seems to contradict findings from the literature that suggests problems associated with the use of corporal punishment in schools (Carlsmith 2002).

The different disciplinary measures for minor forms of indiscipline against given parameters also produced interesting results. Learners believe that disciplinary measures are low on the ability to deter offenders, deter other learners, helping offenders understand disciplinary measures as well as the teaching of responsible behaviour and selfdiscipline. Such findings are consistent with those by Ramadiro and Vally (2005) who state that effective disciplinary measures should teach responsible behaviour and the inculcation of self- discipline and this cannot be achieved through punishment-based disciplinary measures. On disciplinary measures in response to major forms of indiscipline, majority of the learners responses indicate that disciplinary measures such as suspension, expulsion, manual labour, detention and demotion low, suggesting that these measures appear to be ineffective in dealing with major forms of learner indiscipline in schools. In view of this, Carlsmith (2002) argues that current punitive disciplinary measures in schools might not be able to curb learner's indiscipline. Disciplinary measures such as referral to psychologists, guidance and counselling, stress and anger management courses are suggestive of high discipline.

This appears to be a justifiable evidence for Marsh (2000) who contends that there is a need for more innovative approaches to deal with learner's indiscipline. The learners seem to be of the opinion that the effectiveness in deterring offenders and other learners, making learners understand disciplinary problems as well as teaching responsible behaviour and self-discipline could be the way forward. Orvis (2001) contends that the teaching of self-discipline is an important attribute of any meaningful disciplinary measure. In view of this, one of the educators in her interview says that "the learners in my class are particularly disciplined because we lay ground rules we all have to observe and they make sure to keep their own share of the bargain." There is also evidence from the focus group interviews where one of the learners claimed that "our class teacher makes us to feel so special and so we will not want to disappoint him any how".

Through responsible behaviour and self-discipline a learner internalizes expected modes of behaviour and can behave accordingly without fear of being punished but by being aware of the necessity of good conduct (Wienstein et al, 2004). The disciplinary measures in use in schools can be seen as low in their ability to teach behaviour accountability, ensuring future cooperation as well as teaching the handling of conflict. In terms of their behaviour a learner should be aware of both positive and negative consequences of his/her modes of behaviour and this can be an integral part of proactive disciplinary strategies (Canter and Canter 2001).

This indicate that schools fail to teach behaviour accountability and as such leave a lot to be desired and it cannot be business as usual in schools especially in the wake of the increase in the number of cases of indiscipline. The fact that both learners and educators find disciplinary measures ineffective in teaching conflict handling, is indicative of a serious problem associated with the measures in use in schools. Whenever there is a group of people, conflict is inevitable. Hence, it is important to develop meaningful and mutually beneficial relationships in schools and classrooms (Grossman 2003). School and classroom environments are full of conflict and there are a myriad of contributory factors to this conflict. In view of this, Heydenberk et al, (2006) think that conflict is normal, and even a very healthy part of any relationship. People are not necessarily expected to agree on everything at all times. Since conflict is inevitable in relationships, learning to deal with it in a healthy way is crucial. When conflict is mismanaged, it can harm a relationship. But when it is handled in a respectful and positive way, conflict provides an opportunity for growth, ultimately strengthening the bond between and among people (Bodine and Crawford 1998). In this regards, discipline needs to play the role of a referee between the learners, educators and the school governing bodies. The need for conflict management and resolution skills is, therefore, necessary in ensuring that conflict situations do not degenerate into feuds and wars leading to injury and fatalities (Maphosa and Mammen 2011). Wilde (1995) in the same light also observes that learners in schools need to be equipped with skills to handle conflict on their own even without the intervention of educators.

\section{Conclusion}

The study concludes that disciplinary measures that are mostly punitive are ineffective in curbing learner indiscipline in schools. The punitive disciplinary measures used in these schools included inflicting pain (physical or mental) on perpetrators of indiscipline. Such disciplinary measures cannot be effective in teaching self- discipline and good behaviour. These disciplinary measures have also proven be ineffective in deterring offenders and would-be offenders. If schools employ disciplinary measures and pupils still commit more and severe cases of indiscipline despite the punishment, it only serves to show that such measures are counter-productive. The study further concludes that disciplinary measures failed to teach conflict-handling among learners. This account in most part for the gaining ground 
concern on the increasing cases of learner's indiscipline in schools. Thus, disciplinary measures should be able to build in the learners, the sense of responsibility and the ability to handle conflict so as to avoid misunderstanding with others and creating enemies wherever they go.

\section{Recommendations}

Based on the findings, the study suggests learner-centred disciplinary measures where the learners are involved in drawing classroom and school rules. Such an act would make them to feel a sense of ownership of the rules and an obligation and duty to uphold them. These rules can work under this situation because learners would be supportive as opposed resist rules imposed on them.

There is need for teachers to be trained to use supportive measures on the necessity of proactive and cooperative disciplinary measures. We suggest that these disciplinary approaches should not wait until cases of indiscipline are committed because they assist in teaching self-discipline and ways of behaving even in the absence of teachers. Based on the findings of this study, schools need to arrange time to teach conflict resolution skills to learners. In this regard, learners will be enabled to find solutions to their problems without resorting to violence, which often leads to injuries and fatalities in schools. Conflict resolution skills can help learners to handle differences on their own, thus, avoiding gross cases of indiscipline that often occur as a result of petty conflicts between and among learners.

\section{References}

Bodine R, Crawford D 1998. The Handbook of Conflict Resolution Education: A Guide to Building Quality Programs in Schools. San Francisco: Jossey-Bass.

Canter L, Canter M 2001. Assertive Discipline: Positive Behavior Management for Today's Classroom. Santa Monica, CA: Canter and Associates.

Carlsmith KM 2002. Why do we punish? Deterrence and just deserts as motives for punishment. Journal of Personality and Social Psychology, 83(2): 211 - 228.

Cheunyane G 2008. Substance Abuse at School. City Press, 13 July, 2008, P. 5.

Department of Education, Eastern Cape (2010), District statistics, Emis Section, King William's Town.

De Wet, C. 2003. Eastern Cape educator's perception of the causes and the scope of school violence. Acta Criminologica, 16(3): 89-98.

Gershoff ET 2002. Corporal punishment by parents and associated child behaviours and experiences: A meta-analytic and theoretical review. Psychological Bulletin, 128: 539-579.

Grossman H 2003. Classroom Behaviour Management for Diverse and Inclusive School. Littlefield: Rowman.

Heydenberk RA, Heydenberk WR, Tzenova V 2006. Conflict resolution and bullyprevention: Skills for school success. Conflict Resolution Quarterly, 24 (1): 55-69.

Holden GW 2002. Perspectives on the effects of corporal punishment: Comment on Gershoff (2002). Psycholological Bulletin, 128: 590595.

Maphosa C and Mammen KJ 2011. Learner's views on the Effect of Disciplinary Measures in South African Schools. Journal of Social Sciences 28(3):153-160.

Marsh C 2000. Handbook for Beginning Teachers. London: Longman.

McConville S 2003. The Use of Punishment. Willan Publishing: Devon.

Moles OC 1989. Strategies to Reduce Student Misbehavior. Washington, D.C.: Office of Educational Research andlmprovement, U.S. Department of Education.

Mnyaka NM 2006 Exploring the Promotion of Safe Schools in the Eastern Cape: A Whole School Development Approach. M.Ed Dissertation. Pretoria: University of South Africa.

Ngcukana L 2009. Matric pupil killed in fight. Daily Dispatch, 12 November, P. 1.

Noguera PA 2002. How listening to students can help schools to improve. Theory into Practice, 46: 205-211.

Orvis E 2001. A Noncoercive Approach to Student Discipline at Sturgis Charter School. Fellowship Paper: Masachusetts: Massachussets Charter School Fellowship Programme.

Parkey WW, Stahan DB 2002. Inviting Positive Classroom Discipline. National Middle School Association: Westerville.

Ramadiro B, Vally S 2005 (Eds.). Discipline and Punishment, The Rights of Learners. UNICEF: Johannesburg.

RSA. (1996b). South African Schools Act, 84 of 1996. Pretoria: Government Printers.

Sprague RJ, Walker HW 2004. Safe and Healthy Schools: Practical Strategies. New York: Guilford: New York.

Strauss MA 1996. Spanking and the making of a violent society. Pediatrics, 98: 837-842.

Vitto J 2003. Relationship Driven Classroom Management: Strategies that Promote Student Responsibility. Thousand Oaks, CA: Sage.

Weinstein CS, Tomlinson-Clark S, Curran M 2004. Toward a conception of culturally responsive classroom management. Journal of Teacher Education, 55(1): 25-38.

Wilde J 1995. Anger Management in Schools: Alternatives to Student Violence. Lanham, MD. Scarecrow Press, Inc.

Wolfgang $\mathrm{CH}$ 2001. Solving Discipline and Classroom Management Problems. New York: John Wiley and Sons Inc.

Zaibert L 2006. Punishment and Retribution. Ashgate: Aldershot, Hants 